\title{
COMPARISON BETWEEN ORGANIC MATTER CONTENT OF MAIN SOIL ORDERS IN KURDISTAN REGION USING TWO DIFFERENT METHODS.*
}

\author{
M. R. Khoshnaw ${ }^{1}$ \\ Assist. lecturer \\ A. O. Esmail ${ }^{2}$ \\ Professor
}

Dept. Soil and Water. Coll. Agric. University of Salahaddin, Erbil

muslim.khoshnaw@su.edu.krd akram.esmail@su.edu.krd

\section{ABSTRACT}

This study was conducted to compare between two methods of soil organic matter determination for main soil orders in Kurdistan region/Iraq, for this purpose forty-five soil samples were taken then the organic matter was determined using chemical (Walkley-Black (wet) method and loss-on-ignition method (dry) combustion method. The results indicated the significant correlation $(\mathbf{r}=0.88 * *)$ between the studied methods It means there is good adjustment to convert organic matter by loss-onignition method (dry) to Walkley-Black (wet) method organic matter by this linear equation (organic matter by loss-on-ignition $=1.651 *$ Walkley-Black method organic matter +2.1877 ) this equation can be used to convert organic matter by two methods for Mollisols(M), Vertisols(V) and Aridisols(A) in Hawler(H), Sulaimani(S) and Duhok(D) governorates, this equation is very important and economic to determine and convert dry method to wet method, the amount of organic matter for M, V, A was recorded the highest value $\left(49.5,24.8,20 \mathrm{gkg}^{-1}\right)$ respectively for Mollisols, Vertisols, and Aridisols at Hawler (H), Sulaimani (S), and Duhok(D) respectively for (DM5, SV4, DA1) in Duhok Mollisols, Sulaimani Vertisols and Duhok Aridisol respectively for walk- black (wet) method, the highest value for dry method organic matter in Mollisols, Vertisols, Aridisols was recorded $\left(97.6,77.9,50.3 \mathrm{~g} \mathrm{~kg}^{-1}\right)$ for soil orders (MD3, VD4, AD4) respectively.

Keywords: methods of determination, soil texture, Calcium Carbonate.

*Part from Ph.D. dissent a form of the $2^{\text {nd }}$ author

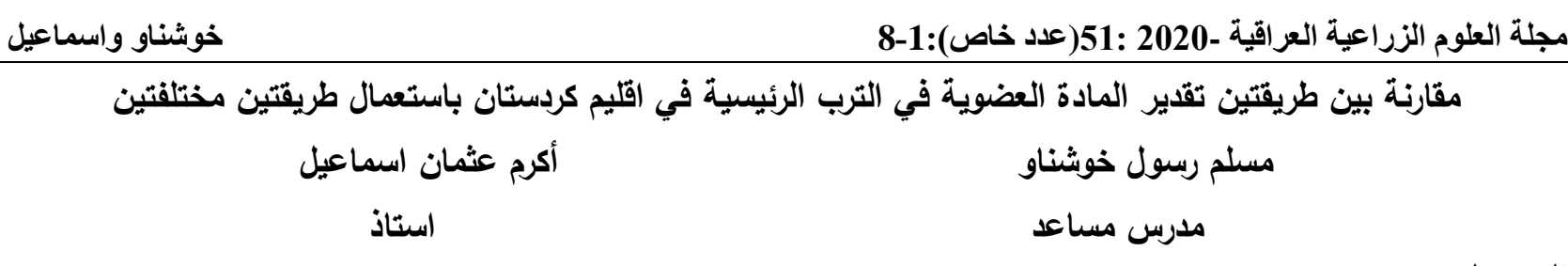
المستخلص

أجريت هذه الدراسة للمقارنة بين طريقتين لتقدير المادة العضوية في رتبة التربة الرئيسية في إقليم كردستان / العرلق ، لهذا

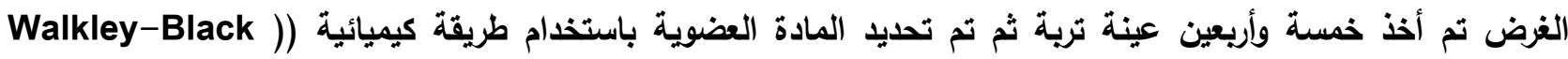

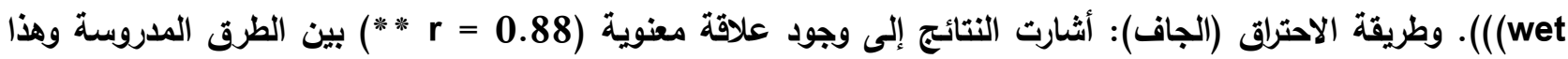

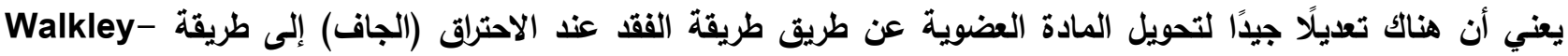
* مادة عضوية بهذه المعادلة الخطية (المادة العضوية عن طريق الفقد أثناء الاحتراق = (Black (wet)) Walkley-Black

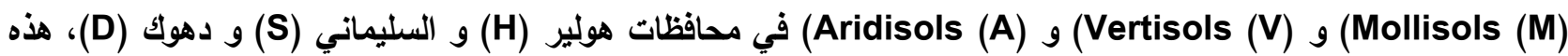
المعادلة مهمة جدًا من الناحية الاقتصادية لتحديد وتحويل الطريقة الجافة إلى الطريقة الرطبة وتم تسجيل كمية المواد العضوية

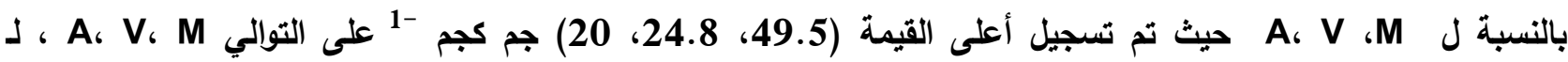

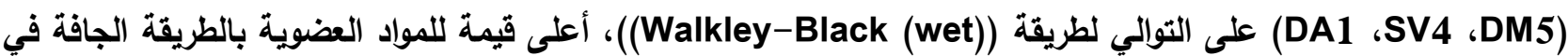

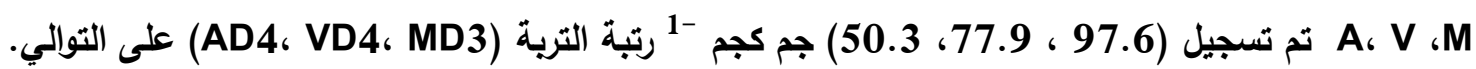
الكلمات المفتاحية: المواد العضوية، طرق تقدير المادة العضوية، رتبة التربة، قوام التربة، كريونات الكالسيوم. 


\section{INTRODUCTION}

Iraqi soils illustration different degrees of development according to the dominant local conditions mainly climatic and geological conditions. The results of the morphological, physical and chemical soil properties indicated to the presence of five soil orders including Aridisols, Entisols, Inceptisols, Mollisols, and Vertisols. Each order shows some variations within the common properties reflecting the effect of the dominant local conditions mainly, climatic and type of parent materials (17). These orders arranged according to their percentage from the total Iraqi area as follow: Aridisols (62.2 \%), Entisols (16.2\%), Inceptisols (12.6\%), Mollisols (3.8\%) and Vertisols $(1.2 \%)$ respectively in Kurdistan regain the dominant orders are Mollisols, Aridisols and Vertisols. When plant residues are returned to the soil, various organic compounds undergo decomposition. Decomposition is a biological process that includes the physical breakdown and biochemical transformation of complex organic molecules of dead material into simpler organic and inorganic molecules (3) Organic matter plays important roles in improving soil physical, chemical, and biological properties. It is considered as a very important parameter of soil fertility and productivity. It provides nutrients to the soil, improves water holding capacity and helps the soil to maintain better aeration and soil quality for seed germination and plant root development $(3,21,30)$. Soil organic matter is considered to be a key influence of soil quality because of its effect on the chemical, physical, and biological properties and processes in soils. Conversely, it is not sensitive to shortterm changes of soil quality with different soil or crop management practices due to high background levels and natural soil variability, it has been suggested by $(14,5)$. Soil organic matter plays an important role in nutrient cycling in tropical ecosystems as well as important for the maintenance of soil structure and fertility $(20,24,25,26)$. Soil organic matter encompasses a diversity of organic compounds with decomposition rates which vary continuously due to the complex interactions of biological, chemical and physical processes in soils (11). It is well known the importance of soil organic matter for soil quality and plant growth. Thus, several methods have been proposed for its measurement $(15,27)$ and several papers discussed the most common ones. The establishment of the relationship among different methods of organic carbon determination is important for soil carbon $(12,22)$. There are little or no studies about the correlation between the methods of organic matter determination for this reason this study was selected to explain the statistical relationship between them. The objective of this study the correlation between soil organic matter content in Kurdistan region using two different methods in different dominant soil orders (Mollisols(M), Vertisols(V) and Aridisols(A)) in Hawler(H), Sulaimani(S) and Duhok(D) in Kurdistan region.

\section{MATERIALS AND METHODS}

Three dominant of (soil orders) were collected from Hawler, Sulaimani and Duhok governorates fifteen samples in each order were taken from the soil surface $(0-30) \mathrm{cm}$ depth to determine the equation to convert organic matter by Walkley-Black method to organic matter by on-ignition method (dry method) or Versa. Forty-five soil samples were taken on November, 2016 from the soil surface (0-30) $\mathrm{cm}$ depth for the dominant soil orders (Mollisols, Aridisol and Vertisols ) in Hawler, Sulaimani and Duhok governorates, fifteen samples were taken in each governorate (5 samples per soil order) were air-dried, thoroughly mixed, and sieved using $2 \mathrm{~mm}$ sieve for soil physical and chemical analysis. The soil analysis included Electrical Conductivity (EC) depending on (23), calcium carbonate $\left(\mathrm{CaCO}_{3}\right)$ depending on., (7), Moisture content according to (10), and field capacity (FC) and wilting point (W.P) were determined according to the models prepared by (8) Particle size distribution was determined by hydrometer method as mentioned by (10). using sodium hexametaphosphate (Calgon) as the dispersing agent. Soil $\mathrm{pH}$ of the saturated extract was measured with pH-meter; model 332 JENWAY, as mentioned by (16). Soil organic matter calculated as the loss-on-ignition method reported by (29). The parameters measured were determined, and the analysis 
was carried out at the soil and water department laboratories, in Agriculture College, at Salahaddin University. Three orders Kurdistan regain soil samples, including Mollisols, Vertisols, Aridisols illustrated in (Table 1)

\section{RESULTS AND DISCUSSION}

Table 1 illustrates some physic-chemical properties of the studied soils such as soil texture, water content, field capacity, saturation past, calcium carbonate, $\mathrm{pH}$, and electrical conductivity for dominate orders in Kurdistan region Table 1 shows the physicchemical properties of for Mollisols, Vertisols, and Aridisols in Hawler, Sulaimani, and Duhok, respectively. The results of the numerical simulation indicate that the soil texture for Mollisols, Hawler and Sulaimani were silty loam the amount of particle size distribution for ( sand, silt, and clay) were $(230,560,200) \mathrm{g} \mathrm{kg}^{-1}$ and $(114.1,455.9,430)$ $\mathrm{g} \mathrm{kg}^{-1}$ in Hawler and Sulaimani respectively, whereas in Duhok was silty clay, the sand, silt, and clay were $(176.2,396.3,427.5) \mathrm{g} \mathrm{kg}^{-1}$. As well as the soil texture of Vertisols in Hawler, Sulaimani and Duhok were silty clay, and amount of sand, silt, and clay were (452.4, $71.9,475.7) \mathrm{g} \mathrm{kg}^{-1},(43.2,400.5,556.3) \mathrm{g} \mathrm{kg}^{-1}$ and $(35,455.8,509.2) \mathrm{g} \mathrm{kg}^{-1}$ respectively, while the soil texture for Aridisols in Hawler and Duhok were clay loam with particle size distribution of $(220.2,509.6,270.2) \mathrm{g} \mathrm{kg}^{-1}$ and (221.1, 413.6, 365.3) $\mathrm{g} \mathrm{kg}^{-1}$ for sand, silt, clay respectively, but for Sulaimani was silty clay loam the amount of sand silt and clay were ( 143.7, 541.8, 314.5) $\mathrm{g} \mathrm{kg}^{-1}$ for sand, silt and clay, respectively, results showed that the increase of clay percentage cause increasing in water content as mentioned by (6) Percentage water content (WC), field capacity, (FC), wilting point (W.P), saturation past (SP), calcium carbonate $\left(\mathrm{CaCO}_{3} \mathrm{~g} \mathrm{~kg}^{-1}\right), \mathrm{pH}$, and electrical conductivity $\left(\mathrm{EC} \mathrm{dSm}^{-1}\right)$ were $(5.05$, $\left.21.25,11.59,39.52,300,7.394,0.36 \mathrm{dSm}^{-1}\right)$ respectively for Hawler Mollisols, while for Sulaimani Mollisols were $(6.0,30.35,19.62$, $\left.56.45,230,7.308,0.54 \mathrm{dSm}^{-1}\right)$ was recorded respectively on the other hand. Duhok Mollisols were $(4.86,30.25,19.53,56.27$, $\left.214,7.536,0.48 \mathrm{dSm}^{-1}\right)$ respectively, so Hawler Vertisols were $(4.24,32.17,21.22$, $\left.59.83,300,7.474,0.4 \mathrm{dSm}^{-1}\right)$ respectively,
Sulaimani Vertisols were $(4.71,35.37,24.04$, 65.78, 268, 7.464, and $0.29 \mathrm{dSm}^{-1}$ ) respectively. Duhok Vertisols were (9.20, $33.50,22.39,62.30,240,7.472$, and $0.36 \mathrm{dSm}^{-}$ $\left.{ }^{1}\right)$. Hawler Aridisols were $(2.34,24.01,14.03$, $44.65,488,7.45$, and $\left.0.5 \mathrm{dSm}^{-1}\right)$ respectively. Sulaimani Aridisols were $(3.78,25.76,15.58$, 47.92, 460, 7.472, and $\left.0.52 \mathrm{dSm}^{-1}\right)$ respectively. Duhok Aridisols were (2.89, 27.78, 17.35, 51.67, 590, 7.492, and $0.4 \mathrm{dSm}^{-}$ $\left.{ }^{1}\right)$ respectively. $(21,18)$ said that the soil organic matter has an important effect on the physicochemical status. Increase the amount of organic matter in the soil improve the physical and chemical properties $(3,9,19)$. The relation between the two methods was significantly reported by $(22,29)$ It has been suggested that soil organic matter is considered to be a key influence of soil quality because of its role on chemical, physical, and biological properties and processes in soils The results indicated that there was a significant correlation between two methods using in the determination of organic matter with the correlation coefficient value of $\left(\mathrm{r}=0.8819^{* *}\right)$ (organic matter by loss-onignition method $=1.651^{*}$ Walkley-Black method organic matter +2.1877$) \mathrm{y}=$ organic matter by muffle method, $\mathrm{X}=$ Walkley-Black method organic matter this equation can be used for convert organic matter by two methods in Mollisols, Vertisols, and Aridisols for Hawler, Sulaimani, and Duhok, in another hand this equation is very important and economic to determine and convert organic matter by the dry method to wet method shown in Figure 1 The figure provides information about the correlation between two methods Walkley-Black method and loss-onignition method for determining organic matter Mollisols, Vertisols, and Aridisols in Kurdistan region. This figure shows a significant correlation ( $\mathrm{r}=0.8819^{* *}$ ) between two methods (Walkley-black) loss-ignition) used in determining organic matter in this soils, as well as the Paired Samples Statistics, are significant for Mollisols, Vertisols, and Aridisols in each order, the highest value for organic matter was recorded in Duhok Mollisols (49.5 $\mathrm{g} \mathrm{kg}^{-1}$ ) for wet method (Walkley-Black) while the lowest value (38.3 $\mathrm{g} \mathrm{kg}^{-1}$ ) was recorded in Hawler Mollisols 
(HM2), as well as the highest value $\left(97.6 \mathrm{~g} \mathrm{~kg}^{-}\right.$ ${ }^{1}$ ) for muffle method (dry method) was also in Duhok Mollisols (DM3), whereas the lowest value $\left(80.9 \mathrm{~g} \mathrm{~kg}^{-1}\right)$ found in Sulaimani Mollisols (SM1). The highest value was recorded for organic matter in Sulaimani Vertisols (SV4) was ( $24.8 \mathrm{~g} \mathrm{~kg}^{-1}$ ) for wet method Walkley-Black, while the highest value for the dry method was recorded in (DV4) was (77.9 $\mathrm{g} \mathrm{kg}^{-1}$ ), where the lowest value $\left(20.4 \mathrm{~g} \mathrm{~kg}^{-1}\right)$ for Vertisols was recorded in Duhok Vertisols for wet method WalkleyBlack, as well as the highest value for muffle method (dry method) in Duhok Vertisols (DV3) was (96.1 $\mathrm{g} \mathrm{kg}^{-1}$ ), so the lowest value $(5.32 \%)$ was recorded in (HV3) in Hawler Vertisols for dry method. The highest value was recorded for organic matter in Duhok Aridisols (DV1) was $\left(20 . \mathrm{g} \mathrm{kg}^{-1}\right)$ in (DA1) for wet method Walkley-Black, while the lowest value in Sulaimani Aridisols (SA5) was (12.9 $\mathrm{g} \mathrm{kg}^{-1}$ ) for wet method Walkley-Black, as well as the highest value for muffle method was $\left(50.3 \mathrm{~g} \mathrm{~kg}^{-1}\right)$ Duhok Aridisols in (AD4) for dry method, whereas the lowest value was recorded in Sulaimani Aridisols (SA2) was (26.3 $\left.\mathrm{g} \mathrm{kg}^{-1}\right)$ in (SA2). All results were shown in table (2) the amount of calcium carbonate was recorded in Aridisols was $\left(590 \mathrm{~g} \mathrm{~kg}^{-1}\right)$ in Duhok, while the lowest value for organic matter in Aridisols Sulaimani was (12.9) for chemical method and (26.3) for dry method, $\mathrm{pH}$ values were around (8) in most of the soils due to the high calcium carbonate content. Total organic carbon contents were generally low because of the semiarid climatological characteristics by low rainfall and high temperatures according to (2), soil organic matter is a very important source of nutrient (11) the impact of feeding different particle sizes of $\mathrm{CaCO}_{3}$ on weight grain and feed conversions of broilers has not been studied extensively. (4) all results illustrated in the table (2).

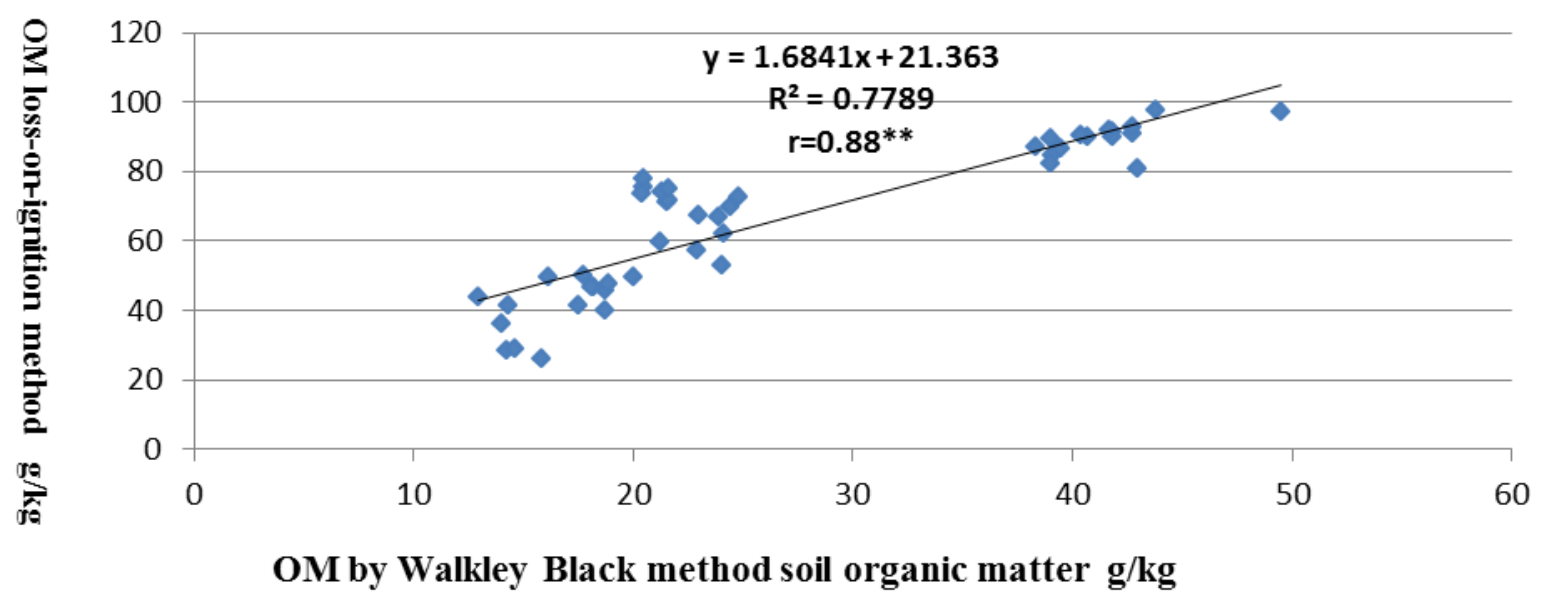

Figure(1) correlation between Walkley-Black and loss-on-ignition method for determine organic matter in dominat soil orders (Mollisols, Vertisol, Aridisol) in Hawler, Sulaimany and Duhok .

Figure 1. correlation between Walkley-Black and loss-on-ignition method for determine organic matter in dominat soil orders (Mollisols, Vertisol, Aridisol) in Hawler, Sulaimany and Duhok 
Table 1 Mean for some chemical and physical properties for dominant soil orders Mollisols, Vertisols, Aridisol in Hawler, Sulaimani and Duhok.

\begin{tabular}{|c|c|c|c|c|c|c|c|c|c|c|}
\hline \multirow{2}{*}{$\begin{array}{c}\text { Treatment } \\
\text { Hawler }\end{array}$} & \multicolumn{3}{|c|}{ Particle Size Distribution $\mathrm{g} \mathrm{kg}^{-1}$} & \multirow{2}{*}{\begin{tabular}{|c|} 
WC\% \\
5.05 \\
\end{tabular}} & \multirow{2}{*}{\begin{tabular}{|c|} 
FC \\
21.25
\end{tabular}} & W P & $\mathbf{S P}$ & $\begin{array}{r}\mathrm{CaCO}_{3} \\
\mathrm{~g} \mathrm{~kg}^{-1}\end{array}$ & $\mathbf{p H}$ & $\begin{array}{l}E C \\
d S m^{-1}\end{array}$ \\
\hline & Sand & 230 & Silty loam & & & 11.59 & 39.52 & 300 & 7.394 & 0.36 \\
\hline \multirow[t]{2}{*}{ Mollisols } & Silt & 560 & & & & & & & & \\
\hline & Clay & 200 & & & & & & & & \\
\hline Sulaimany & Sand & 114.1 & Silty loam & 6.00 & 30.35 & 19.62 & 56.45 & 230 & 7.308 & 0.54 \\
\hline \multirow[t]{2}{*}{ Mollisols } & Silt & 455.9 & & & & & & & & \\
\hline & Clay & 430 & & & & & & & & \\
\hline Duhok & Sand & 176.2 & Silty clay & 4.86 & 30.25 & 19.53 & 56.27 & 210 & 7.536 & 0.48 \\
\hline \multirow[t]{2}{*}{ Mollisols } & Silt & 396.3 & & & & & & & & \\
\hline & Clay & 427.5 & & & & & & & & \\
\hline Hawler & Sand & 452.4 & Silty clay & 4.24 & 32.17 & 21.22 & 59.83 & 300 & 7.474 & 0.41 \\
\hline \multirow[t]{2}{*}{ Vertisols } & Silt & 71.9 & & & & & & & & \\
\hline & Clay & 475.7 & & & & & & & & \\
\hline Sulaimani & Sand & 43.2 & Silty clay & 4.71 & 35.37 & 24.04 & 65.78 & 268 & 7.464 & 0.29 \\
\hline \multirow[t]{2}{*}{ Vertisols } & Silt & 400.5 & & & & & & & & \\
\hline & Clay & 556.3 & & & & & & & & \\
\hline Duhok & Sand & 35.0 & Silty clay & 9.20 & 33.50 & 22.39 & 62.30 & 240 & 7.472 & 0.36 \\
\hline \multirow[t]{2}{*}{ Vertisols } & Silt & 455.8 & & & & & & & & \\
\hline & Clay & 509.2 & & & & & & & & \\
\hline Hawler & Sand & 220.2 & Clay loam & 2.34 & 24.01 & 14.03 & 44.65 & 488 & 7.45 & 0.5 \\
\hline \multirow[t]{2}{*}{ Aridisol } & Silt & 509.6 & & & & & & & & \\
\hline & Clay & 270.2 & & & & & & & & \\
\hline Sulaimani & Sand & 143.7 & Silty clay & 3.78 & 25.76 & 15.58 & 47.92 & 460 & 7.472 & 0.53 \\
\hline \multirow[t]{2}{*}{ Aridisol } & Silt & 541.8 & loam & & & & & & & \\
\hline & Clay & 314.5 & & & & & & & & \\
\hline Duhok & Sand & 221.1 & Clay loam & 2.89 & 27.78 & 17.35 & 51.67 & 590 & 7.492 & 0.4 \\
\hline \multirow[t]{2}{*}{ Aridisol } & Silt & 413.6 & & & & & & & & \\
\hline & Clay & 365.3 & & & & & & & & \\
\hline
\end{tabular}


Table 2. The soil organic matter content of the studied soil samples using Walkley-Black and muffle methods for determine organic matter in Hawler, Sulaimani, Duhok, for two different methods

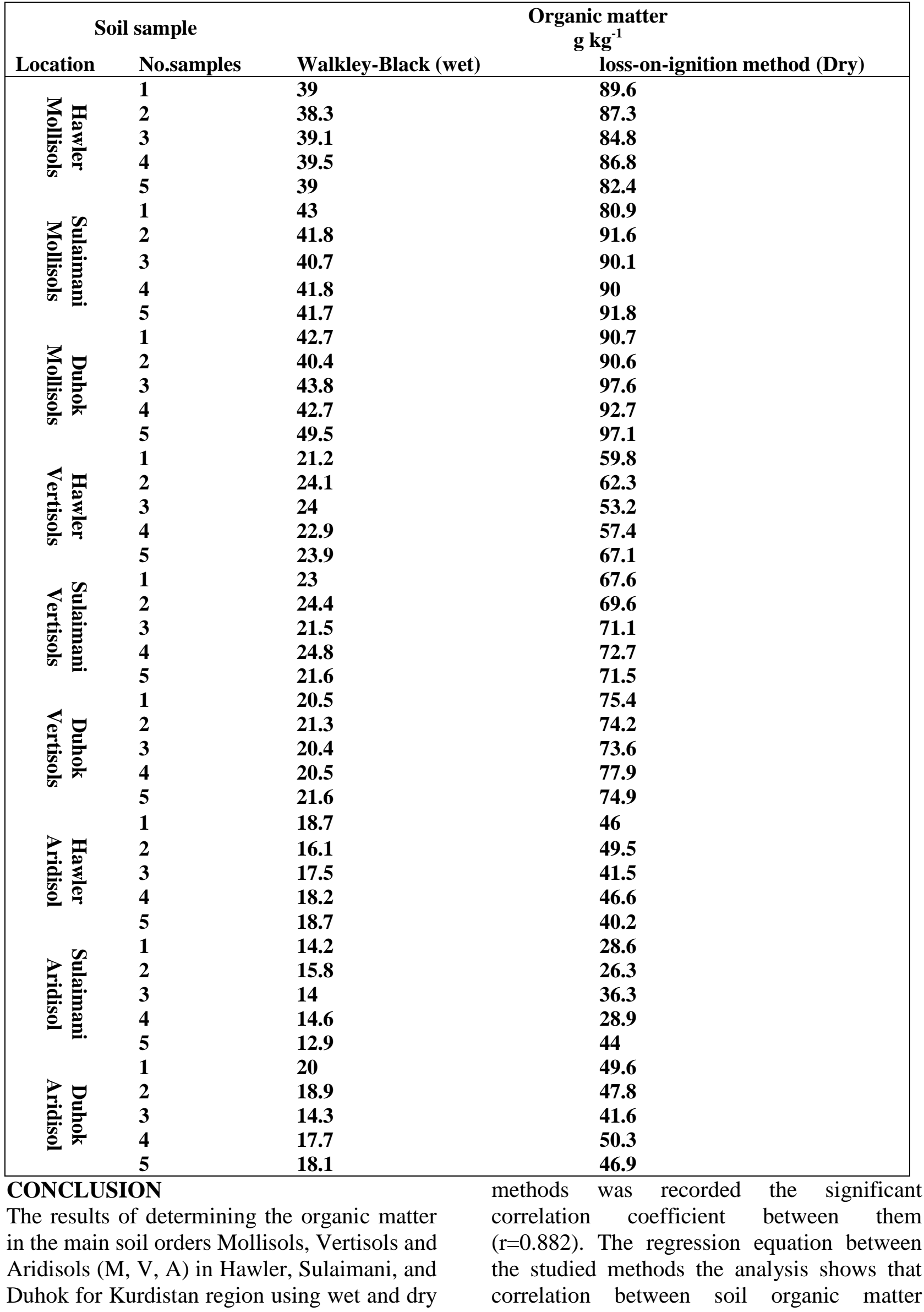


content for soil orders in Kurdistan region using two different methods was a significant with correlation coefficient value of $(\mathrm{r}=0.882)$, and determine the amount of organic matter to three dominant orders in the surface $(0-30$ $\mathrm{cm}$ ), also determine the equation for estimate organic matter in three orders convert organic by the wet method to dry method and versa by linear equation. The best for determination of the organic matter is the wet method cause more accuracy. Result illustrated that recommended to determine the organic matter by this equation (organic matter loss-onignition method $=1.651^{*}$ organic matter(Walkley-Black method) +2.1877$)$ this is the economic method to determine the organic matter by wet or dry

\section{REFERENCES}

1. Bonde, T.A., B.T, Christensen and C.C, Cerri 1992. Dynamics of soil organic matter as reflected by natural $13 \mathrm{C}$ abundance in particle size fractions of forested and cultivated oxisols. Soil Biology and Biochemistry, 24(3):.275-277

2. Caravaca, F., A, Lax. and J, Albaladejo 1999. Organic matter, nutrient contents and cation exchange capacity in fine fractions from semiarid calcareous soils. Geoderma, 93(3-4):.161-176

3. Ding, G., X, Liu., S,.Herbert, J, Novak,. D, Amarasiriwardena and B., Xing, 2006. Effect of cover crop management on soil organic matter. Geoderma, 130(3-4):.229-239

4. Guinotte, F, Y, Nys and F, De Monredon 1991. The effects of particle size and origin of calcium carbonate on performance and ossification characteristics in broiler chicks. Poultry Science, 70(9), :.1908-1920

5. Haynes, RJ 2005 Labile organic matter fractions as central components of the quality of agricultural soils: an overview. AdvAgron 85:221-268

6. Hudson, B.D 1994. Soil organic matter and available water capacity. Journal of Soil and Water Conservation, 49(2):.189-194

7. Issam, I.B. and H.S, Antoine 2007. Methods of Analysis for Soils of Arid and Semi-arid Regions. Food and Agriculture Organization of the United Nations, Rome

8. Karim, T. H. 2000. Models to predict water retention of Iraqi soils. Indian J. of soil Sci. 47: $19-23$.
9. Khidr, S. K. 2018. Effects of organic fertilizers and wheat varieties on infestation by, corn leaf aphid, rhopalosiphum maidis and wheat thrips, Haplothrips tritici and their predators. Iraqi Journal of Agricultural Sciences, 49(1).

10. Klute, A. 1986. Methods of Soil Analysis. Part 1. Agronomy 9. Soil Science Society of America, Madison, Wisc

11. Konare, H., R.S, Yost, M, Doumbia, G.W, McCarty, A, Jarju, . and R, Kablan 2010. Loss on ignition: measuring soil organic carbon in soils of the Sahel, West Africa. African Journal of Agricultural Research, 5(22):.30883095

12. Lettens, S., B, De Vos., P. Quataert, B, Van Wesemael, B, Muys, and J, Van Orshoven, 2007. Variable carbon recovery of Walkley-Black analysis and implications for national soil organic carbon accounting. European Journal of Soil Science, 58(6):.1244-1253

13. Liu, B., C, Tu, S, Hu, M, Gumpertz, and J.B, Ristaino 2007. Effect of organic, sustainable, and conventional management strategies in grower fields on soil physical, chemical, and biological factors and the incidence of Southern blight. Applied Soil Ecology, 37(3):.202-214

14. Magdoff, F,and R.R, . Weil 2004. Soil organic matter management strategies. Soil organic matter in sustainable agriculture. CRC press

15. Mebius, L. 1960. A rapid method for the determination of organic carbon in the soil. Analytica Chimica Acta, 22:.120-124

16. Motsara, M.R. and R.N, Roy 2008.Guide to laboratory establishment for plant nutrient analysis (Vol. 19). Rome: Food and Agriculture Organization of the United Nations

17. Muhaimeed, A.S., A.J, Saloom, K.A, Saleim and K.A, Alaane 2014. Classification and distribution of Iraqi Soils. Int $\mathbf{J}$ Agric Innov Res, 2(6):.2319-1472

18. Muhawish, N.M. and R.K, Al-Kafaje 2017. Soil organic carbon and phosphorus status after combined application of phosphate rock and organic materials in agypsiferous soil. The Iraqi Journal of Agricultural Science: 48:.60 
19. Muneer, N.Y. and K.M, Rabee, 2017. Effect of different types of organic fertilizer in vegetative growth of cacats (Aloe Vera L.). The Iraqi Journal of Agricultural Science, 48(3):.701

20. Nieder, R, D K, Benbi. 2008. Carbon and Nitrogen in the Terrestrial Environment. Springer, Heidelberg. ntify organic and carbonate carbon of sediments from diverse sources. Environmental Monitoring and Assessment 174: 241-257

21. Oorts, K., B Vanlauwe,. and R, Merckx, 2003. Cation exchange capacities of soil organic matter fractions in a ferric lixisol with different organic matter inputs. Agriculture, Ecosystems \& Environment, 100(2-3), 161171

22. Rahman, M.H., A.W, Holmes, M, Deurer, S.J, Saunders, A, Mowat and B.E, Clothier 2011. Comparison of three methods to estimate organic carbon in allophanic soils in New Zealand. In $24^{\text {th }}$ Annual Workshop. pp 39

23. Rowell, D. L. 1996. Soil science. Methods and application. Univ. of Reading. UK

24. Sanchez, P. A. and R. H, Miller. 1986 Organic matter and soil fertility management in acid soils of the tropics. International Society of Soil Science Transactions $13^{\text {th }}$ Congress 6: 609-625
25. Shang, C. and H, Tiessen, 1998. Organic matter stabilization in two semiarid tropical soils: size, density, and magnetic separations. Soil Science Society of America Journal, 62(5):.1247-1257

26. Solomon, D., J, Lehmann and W, Zech. 2000. Land use effects on soil organic matter properties of chromic luvisols in semi-arid northern Tanzania: carbon, nitrogen, lignin and carbohydrates. Agriculture, Ecosystems \& Environment, 78(3):.203-213

27. Walkley, A. and I. A, Black 1934. An examination of the Degtjareff method for determining soil organic matter, and a proposed modification of the chromic acid titration method. Soil science, 37(1):.29-38

28. Wander, M.M., M.G, Bidart. and S, Aref 1998. Tillage impacts on depth distribution of total and particulate organic matter in three Illinois soils. Soil Science Society of America Journal, 62(6):.1704-1711

29. Wang, X.J, P.J, Smethurst,.and A.M, Herbert 1996. Relationships between three measures of organic matter or carbon in soils of eucalypt plantations in Tasmania. Soil Research, 34(4):.545-553

30. Zia, M.S. 1993. Soil Fertility Evaluation and Management for Flooded Lowland-Rice Soils of Pakistan. Ph.D. Dissertation Kyoto University, Japan. 